\title{
Environmental Application of Ultrasonic Irradiation
}

\author{
Duk Kyung Kim ${ }^{1 *}$ and Daye Chun ${ }^{2}$ \\ ${ }^{1}$ Professor, Department of Chemistry, Auburn University Montgomery, USA \\ ${ }^{2}$ Nanopac Co., Ltd. 673 Hwasan-Ri, Cheoin-Gu, Yongin-Si, Gyeonggi-Do, Korea
}

Submission: August 29, 2018; Published: September 12, 2018

*Corresponding author: Duk Kyung Kim,Professor, Department of Chemistry, Auburn University Montgomery, USA, Tel: +1 334244 3329; Fax: +1 334244 3826; Email: dkim@aum.edu

\section{Abstract}

The ultrasound waves $(20 \mathrm{kHz}$ to several hundred $\mathrm{kHz})$ generated from the conversion of electric pulses by using a transducer can cause dramatic chemical and physical effects. Cavitating bubbles formed under ultrasonic irradiation produce high temperature and pressure conditions (up to 5,000K and 1,000 atm) inside the bubbles and as a consequence reactive oxygen species and many other reactive radicals are produced. The ultrasonic irradiation technique for cleaning polluted water has several merits over the other typical advanced oxidation technologies (AOTs) because this technique does not require chemical additives or catalystsand is independent of the color of the polluted water.

Keywords: Ultrasonic Irradiation; Cleanup of Polluted Water; Soil Remediation

\section{Examples of Environmental Application}

Ultrasonic irradiation is a powerful way to degrade a variety of pollutants and toxic chemicals [1-3]. Demonstrated examples for ultrasonic removal in aqueous media include fuel oxygenates [4], a variety of chlorinated compounds [5], series of phenols [6,7], arsenic species [8], polycyclicaromatic compounds [9], textile dyes $[10,11]$, and surfactants [12]. The sonochemical effect can be economically enhanced by combining other means with ultrasound. Such hybrid methods have been reported by using ultrasound with $\mathrm{H} 2 \mathrm{O} 2$ or 03 [12], solid particles or catalyst [13], or Fenton reagent [14].Because the irradiation of ultrasound is simple and has low impact on fish and aquatic plants, ultrasound has been widely studied for control of cyanobacteria as well as algal control $[15,16]$.The disintegration of bacterial cells is effectively achieved by using high power ultrasonic irradiation with low frequencies, and its effect is enhanced by combining it with UV irradiation [17]. Ultrasonic irradiation can reduce the quantity of chemicals required for water treatment facilities [18].Despite the fact that membrane technologies are widely accepted for the separation of solids from liquid, fouling is one of the serious problems with this technology [19]. Ultrasonic irradiation has been demonstrated to be effective for membrane cleaning by producing reactive oxygen species [20] with the advantage of possible ultrasonic defouling even with an actively operating membrane. Soil remediation is another field where ultrasonic irradiation can be applied to the environmental cleanup. Ultrasonic irradiation enhances the flushing of soils which are contaminated by hydrocarbons [21]. Effective removal of heavy metals from contaminated soil is possible by applying ultrasound to the soil in aqueous media [22].

\section{Conclusion}

The environmental application of ultrasound has been drawing attention for many decades. This area covers the broad ranges of polluted water decontamination, soil remediation, membrane defouling, and decontamination of soils. Application of ultrasound in aqueous media produces both chemical and physical (mechanical) effects which are useful in purification and separation for solving environmental problems with simple and compact means. It is easy to combine ultrasonic technique with the other conventional treatment methods to reduce operational costs.

\section{References}

1. Hoffmann MR, Hua I, Hochemer R (1996) Application of ultrasonic irradiation for the degradation of chemical contaminants in water. UltrasonicsSonochemistry 3(3): S163-S172.

2. Mahamuni MN, Adewuyi YG (2010) Advanced oxidation processes (AOPs) involving ultrasound for waste water treatment: A review with emphasis on cost estimation.UltrasonicsSonochemistry 17(6): 9901003.

3. Pham TD, Shrestha PA, Virkutyte J, Sillanpaa M (2009) Recent studies in environmental applications of ultrasound. Canadian Journal of Civil Engineering 36: 1849-1858.

4. Kim DK, OShea KE, Cooper WJ (2012) Mechanistic considerations for the degradation of methyl tert-butyl ether (MTBE) by sonolysis: Effect of argon vs. oxygen saturated solutions.UltrasonicsSonochemistry 19(4): 959-968. 
5. Jiang Y, Petrier C, Waite TD (2002) Kinetics and mechanisms of ultrasonic degradation of volatile chlorinated aromatics in aqueous solution.UltrasonicsSonochemistry 9(6): 317-323.

6. Entezari MH, Petrier C, Devidal P (2003) Sonochemical degradation of phenol in water: A comparison of classical equipment with a new cylindrical reactor.UltrasonicsSonochemistry 10(2): 103-108.

7. Teo KC, Xu Y, Yang C (2001) Sonochemical degradation for toxic halogenated organic compounds.UltrasonicsSonochemistry 8(3): 241246.

8. Xu T, Cai Y, Mezyk SP, O'Shea KE (2005) The roles of hydroxyl radical, superoxide anion radical, and hydrogen peroxide of arsenite by ultrasonic irradiation. Advances in Arsenic Research: American Chemical Society pp. 333-343.

9. Manariotis I, Karapanagioti HK, Chrysikopoulos CV (2018) Degradation of PAHs by high frequency ultrasound. Water Research 45(8): 25872594.

10. Vajnhhandl S, Le Marechal AM (2005) Ultrasound in textile dyeing and decolouration/mineralization of textile dyes. Dyes and Pigments 65(2): 89-101.

11. Abu-hassan MA, Kim JK, Metcalfe IS, Mantzavinos D (2007) Kinetics of low frequency sonodegradation of linear alkylbenzene sulfonate solutions. Chemosphere 62(5): 749-755.

12. He Z, Song S, Ying H, Xu L, Chen J (2007) p-Aminophenol degradation by ozonation combined with sonolysis: Operating conditions influence and mechanism. UltrasonicsSonochemistry 14(5): 568-574.

13. Qiu P, Park B, Choi J, Thokchom B, Pandit AB, et al. (2018) A review on heterogeneous sonocatalyst for treatment of organic pollutants in aqueous phase based on catalytic mechanism. UltrasonicsSonochemistry 45: 29-49.
14. Yasman Y, Gridin V, Agur VV, Galil S, Armon R, et al. (2004) A new sonoelectrochemical method for enhanced detoxification of hydrophilic chloroorganic pollutants in water.UltrasonicsSonochemistry 11(6): 365-372.

15. Song W, de la Cruz AA, Rein K, OShea KE (2006) Sonochemically induced degradation of microcystin-LR and -RR: Identification of products, effect of $\mathrm{pH}$, formation and destruction of peroxides. Environmental Science \& Technology 40(12): 3941-3946.

16. Park J, Church J, Son Y, Kim KT, Lee WH (2017) Recent advances in ultrasonic treatment: Challenges and field applications for controlling harmful algal blooms (HABs).UltrasonicsSonochemistry 38: 326-334.

17. Blume T, Neis U (2004) Improved wastewater disinfection by ultrasonic pre-treatment.UltrasonicsSonochemistry 11(5): 333-336.

18. Mason TJ, Joyce E, Phull SS, Lorimer JP (2003) Potential uses of ultrasound in the biological decontamination of water. UltrasonicsSonochemistry 10(6): 319-323.

19. Zhang Y, Love N, Edwards M (2009) Nitrification in drinking water systems. Critical Review in Environmental Science and Technology 39(3): 153-208.

20. Li X, Yu J, Nnanna AGA (2011) Fouling mitigation for hollow-fiber UF membrane by sonication. Desalination 281:23-29.

21. Kim YU, Wang MC (2003) Effect of ultrasound on oil removal from soils.Ultrasonics 41(7): 539-542.

22. Park B, Son $Y$ (2017) Ultrasonic and mechanical soil washing processes for the removal of heavy metals from soils.UltrasonicsSonochemistry 35: 640-645.

Your next submission with Juniper Publishers will reach you the below assets

his work is licensed under Creative

Commons Attribution 4.0 License

DOI: 10.19080/IJESNR.2018.14.555883 